\title{
The Influence of the Avicennan Theory of Science on Philosophical Sufism
}

\section{The Concept of the Divine Science in Qūnawì and Fanārì}

\author{
Yusuf Daşdemir \\ University of Jyväskylä, Jyväskylä, Finland \\ dasdemiry@hotmail.com
}

\begin{abstract}
This article discusses the application of the Avicennan theory of demonstrative science on tașawwuf, or the Divine Science (al-ilm al-ilāhī), by members of the Akbarian tradition, particularly Ibn 'Arabī's (d. 1240) stepson and most influential disciple, Șadr al-Dīn al-Qūnawī (d. 1274), and his commentators, among whom the most prominent was Mullā Muhammad b. Hamza al-Fanārī (d. 1431). It aims to find out what kind of relationship was developed between Avicennan logic and Sufism by the two members of the Akbarian school in the post-classical Islamic thought. It also seeks to show that the convergence between different currents of Islamic thought-Sufism and philosophy in this case-led to some adaptation problems and internal inconsistencies for these currents.
\end{abstract}

\section{Keywords}

Avicennan theory of demonstrative science - Akbarian tradition of Sufism - Șadr alDīn al-Qūnawī - Mullā Fanārī

\section{Introduction}

It is well known that we owe to Aristotle (d. $322 \mathrm{BCE}$ ), among other things in philosophy and logic, a novel concept of science, namely the theory of demonstrative science. In the first eight chapters of his Posterior Analytics I, Aristotle proposes for the first time a full-fledged theory of the constitution and structure of demonstrative sciences, or, to put this a bit differently, of the logical 
model that the scientific branches must comply with. ${ }^{1}$ According to the theory, each scientific discipline must have tripartite content: taking (1) a certain range of things or phenomena as its peculiar subject matter and (2) a limited number of unproven definitions and propositions as its principles, while trying (3) to demonstrate some questions related to whether and why some attributes belong to the genus, which constitutes the subject matter of the discipline at hand.

As Marmura observes, "in its medieval Islamic journey, the Posterior Analyt$i c s$, fared very well. It exerted enormous influence on Arabic thought." ${ }^{2}$ Aristotle's Posterior Analytics was first and foremost a work on his ideas about demonstration and demonstrative science and actually Arabic logicians took it that way as clearly evidenced by the fact that they almost unanimously named the book after the theory of demonstration, namely Kitāb al-burhān, or "the book of demonstration."3 Avicenna (Ibn Sīnā, d. 1037) devotes Kitāb al-burhān II.6 of his al-Shifä to the discussion of the so-called elements of the demonstrative sciences, opening with the statement that "each of the arts (șinā $c \bar{a} t)$, particularly the theoretical ones, has principles (mabād $\vec{l})$, subject matters (mawdị $\bar{a} t)$ and problems (masäil or mațālib)." According to him, the principles of any given science are those premises from which the art is demonstrated and which

1 Although he must have had some predecessors in terms of the notion of demonstrative science, most probably among mathematicians and members of the Academy, Aristotle was the first to build such a well-structured theory out of some scattered elementary ideas, in order for a discipline to be science in the real or strict sense of the term. For a history of demonstrative, or axiomatized, science and its elements before Aristotle, see Árpád Szabó, "Greek Dialectic and Euclid's Axiomatics," in Problems in the Philosophy of Mathematics, ed. by I. Lakatos (Amsterdam: North-Holland Pub., 1967), 1-8. For a critical exposition of the idea and more bibliographical information, see Jonathan Barnes, "Aristotle's Theory of Demonstration," Phronesis 14, no. 2 (1969), 123-52, esp. 128-32, and "Introduction," in Aristotle, Posterior Analytics, trans. by Jonathan Barnes (Oxford: Clarendon, 1993), xx.

2 M.E. Marmura, "The Fortuna of the Posterior Analytics in the Arabic Middle Ages," in Knowledge and the Sciences in Medieval Philosophy, ed. by M. Asztalos et al. (Helsinki: Acta Philosophica Fennica, 1990), vol. I, 85-103, esp. 103 .

3 At the very beginning of the Arabic translation of Aristotle's Posterior Analytics, it was noted that this book had been known as "the book of demonstration." Since then, the latter term has been so prevalent as to make the former name almost obsolete, especially in the postclassical period of Islamic thought. See Manțiq Arisțū, ed. by A. Badawī (Beirut: Dār al-qalam, 1980), vol. II, 329 .

4 Ibn Sīnā, al-Shifä̀) al-Manțiq v: al-Burhān, ed. by A. 'A. al-'Afîfī (Cairo: al-Mațba'a al-amīriyya, 1956), 155.4-5. For a study of Avicenna's and also Fārābī's views on the elements of demonstrative sciences and the terminology, see Heidrun Eichner, "Al-Fārābī and Ibn Sīnā on 'Universal Science' and the System of Sciences: Evidence of the Arabic Tradition of the Posterior Analytics," Documenti e studi sulla tradizione filosofica medievale 21 (2010), 71-95. 
are not proven within the art itself. The subject matter comprises the thing(s), whose states $(a h w \bar{a} l)$ and essential accidents are investigated within the art, whereas the problems are the premises whose predicates are essential accidents of the subject matter, or its species or accidents. ${ }^{5}$

Although this Aristotelian/Avicennan theory of science was initially welcomed only by philosophers in the Islamic world, after Ghazālī's (d. 1111) famous legitimization and even encouragement of engagement with Aristotelian logic, ${ }^{6}$ certain scholars associated with various Islamic sciences also began to consider reshaping their own disciplines according to the Avicennan concept of demonstrative science. ${ }^{7}$ From the $13^{\text {th }}$ century onward, Islamic mysticism (tasawwuf), ${ }^{8}$ or more precisely, the philosophizing strand of Sufism became subject to such a reconstruction endeavor at the hands of the members of the so-called Akbarian school, beginning with Ibn 'Arabī's (d. 1240) stepson and most influential disciple, Ṣadr al-Dīn al-Qūnawī (d. 1274), ${ }^{9}$ and his commenta-

5 Ibn Sīnā, al-Burhān, 155·5-10.

6 One of the most influential figures in the history of Islam, Ghazāli played a highly crucial role, especially in extending to logic a respected status in Islamic scholarship and in the madrasa curricula. To do so, he first declared that logic is innocuous and neutral by saying that "nothing from logic relates to religion in a positive or negative way;" see Munqidh min al-ḍalāl, in Majmū'a rasāil al-Imām al-Ghazālī, ed. by A. Shams al-Dīn (Beirut: Dār alkutub al-ilmiyya, 1988), 40. He then claimed that logic was used in the Quran and it was such an important propaedeutic for all the sciences that whoever did not master it would not have had reliable knowledge. For the last two points, see Abū Hāmid al-Ghazālī, al-Qistāa s al-mustaqīm, ed. by M. Bayjū (Damascus: al-Mațba'a al-'ilmiyya, 1993); al-Musțaşā min 'ilm al-uṣūl, ed. by M. 'A. 'Abd al-Shāfĩ (al-Mațba'a al-'ilmiyya, 1993), vol. I, 10. For a general account of Ghazālī's logic, see 'Azmī T. al-Sayyed Ahmad, al-Ghazālī's Views on Logic (PhD dissertation, Edinburgh, 1981); Rafīq al-'Ajam, al-Mantiq 'inda l-Ghazālī (Beirut: Dār al-mashriq, 1989).

7 For a study of a similar intellectual enterprise in the case of Islamic jurisprudence, see Abdurrahman Atçıl, "Greco-Islamic Philosophy and Islamic Jurisprudence in the Ottoman Empire (1300-16oo): Aristotle's Theory of Sciences in Works on Ușūl al-Fiqh," The Journal of Ottoman Studies 41 (2013), 33-54.

8 Throughout the paper, I use the terms tașawwuf, 'Sufism' and 'Islamic mysticism' interchangeably, but I think Dagli's concerns about using the last two to render the first, tașawwuf, should be borne in mind. For his views on translating original terms of Islamic culture (including tașawwuf) into European languages, see Caner K. Dagli, Ibn al-'Arabī and Islamic Intellectual Culture (London \& New York: Routledge, 2016), 11-6.

9 For Qūnawī's life and work, see William C. Chittick, "The Last Will and Testament of Ibn 'Arabi's Foremost Disciple Sadr al-Din Qunawi," Sophia Perennis 4, no. 1 (1978), 43-58; Richard Todd, The Sufi Doctrine of Man: Șadr al-Dīn al-Qūnawı̀s Metaphysical Anthropology (Leiden: Brill, 2014), 13-43, who gives a detailed biography of Qūnawī with valuable bibliographical notes. See also Ekrem Demirli, Sadreddin Konevîde bilgi ve varlık (İstanbul: Kapı, 2014), 1431. 
tors, among whom the most prominent and influential was Mullā Muḥammad b. Ḥamza al-Fanārī (d. 1431)..$^{10}$ This paper will deal with the attempts by Qunawī and Fanārī to re-conceptualize tașawwu f as a demonstrative science along Avicennan lines, or, more appropriately, as the Divine Science (al-ilm al-ilăhī), as they called it. It aims to find out what kind of relationship was developed between Avicennan logic and Sufism by the two members of the Akbarian school in the case of the elements of demonstrative sciences and, more specifically, what kind of challenges this relationship raised for them. Given the fact that there is little research on Qūnawì's and especially Fanāri’s attempts to integrate Avicenna's theory of science into Sufism, ${ }^{11}$ this work is expected to address a lacuna in the literature of philosophical Sufism on the one hand and the aftermath of Arabic logic in the post-Classical period of Islamic thought on the other.

10 Given that he was a highly respected scholar, Sufi and bureaucrat of the early Ottoman period, Mullā Fanārī seems not to have been given the attention he deserves in the secondary literature. A very brief account of his career is thus in order. The first Shaykh al-Islām of the Ottoman Empire, Mullā Fanārī was one the most influential figures in the history of the Ottoman scientific tradition. Together with another member of the Akbarian tradition, Dāwūd al-Qaysarī (d. 1350), he was responsible for extending to Sufism a respected status among religious scholars and making it an indispensable part of the philosophical and religious system of the nascent empire. He elaborated and expanded on Qūnawī's teachings on tașawwuf in his commentary on the latter's Miftăhal-ghayb, which has, with its commentary by Fanārī, become the standard textbook on what is called philosophical mysticism in the Islamic world, particularly in Persia and Anatolia. Therefore, Fanārī stands out as the first and foremost commentator of Qūnawī in the area of philosophical Sufism. He also wrote very influential works on other areas of Islamic scholarship, especially in the theory of jurisprudence (ușül al-fiqh), Quranic exegesis (tafsìr) and logic. His career as a logician is of interest to us, because his success in reshaping tașawwuf as a deductive science heavily depended on his great acquaintance with Avicennan logic. In accordance with the tradition of the time, Mullā Fanārī wrote a commentary (known as al-Fawāid al-Fanāriyya) on the most widely read and commented upon text of postClassical Islam, İsāghüjī fí l-manțiq of Athīr al-Dīn al-Abharī (d. 1265). His commentary has attracted great attention from Ottoman scholars; it has been read up until today in the madrasas and glossed by a number of scholars from different generations. Its introduction, which is on the nature and features of the sciences, has special relevance to our subject, as will be seen in the following. On Fanārīs life and work, see Betül Gürer, Molla Fenari'nin varlık ve bilgi anlayışı (İstanbul: İnsan, 2016), 31-69; İ. Hakkı Aydın \& Tahsin Görgün, "Molla Fenari," in Türkiye diyanet vakfi İslam ansiklopedisi (DIA) 30 (2005), 245-8.

11 Perhaps the most noteworthy in this regard is Anthony F. Shaker, Thinking in the Language of Reality: Sadr al-Dīn Qūnawī (1207-74 CE) and Mystical Philosophy of Reason (n.p.:Xlibris, 2015), but it is meant to situate Qūnawī's philosophy within the historical, or rather philosophical context, rather than focusing on the textual analysis of Qūnawī's views. Moreover, it does not extend a special place to Fanārī. 
Qūnawī is generally credited with marking a turning point in the history of Sufism on account of his presentation of tasawwuf according to substantially Avicennan conception of science by determining its elements as a demonstrative science. In his magnum opus, the Miftāh al-ghayb, Qūnawī talks for the first time about the subject matter, principles and problems of tasawwuf - or, to put it in his own terms, the Divine Science. Commenting upon the Miftăh al-ghayb in his Miṣbạh al-uns, Fanārī notably expands and elaborates on this new conception of Sufism, paving the way for a complex and well-structured intellectual tradition still alive in the Islamic world today.

Having said that, I have to contend that neither Qūnawī nor Fanārī clearly designates their discipline as a demonstrative science along Avicennan lines. On the contrary, Qūnawī strives very hard to distance himself from philosophers and logicians as well as theologians, all of whom he often pejoratively calls "the scholars of superficiality ('ulamä' al-rusūm)" and constantly highlights that his views are definitely not learnt from anyone through perusing their books. He tries to explain away the apparent similarity between his vocabulary and that of the logicians, as we will show below. Moreover, he seems rather sceptical of usefulness of the rational and demonstrative conduct of research as a method to obtain the true realities of things, as he explains at length in his al-Risäla al-mufșiha. ${ }^{12} \mathrm{He}$, however, utters his hope "to combine the conclusions derived from logical proofs and the fruits of unveiling and direct vision."13 Fanārī, on the other hand, carefully underlines the character of the Divine Science as a religious (shar $i$ ) discipline essentially complying with the religious instructions, but he seems to share his master's hope to combine, or reconcile respective outcomes of the rational demonstrative way and the spiritual visionary way of knowledge when he states as an aim of his commentary Mișbăh al-uns "to familiarize those principles obtained through unveiling (kashfiyya) with that which the intellect of those veiled by rational reasoning and demonstration agrees about."14 $\mathrm{He}$ also feels need to note as an aspect

12 Șadr al-Dīn al-Qūnawī, al-Risāla al-mufșiha, in Annäherungen: Der mystisch-philosophische Briefwechsel zwischen Șadrud-Dīn-i Qōnawīund Nașir ud-Dìn-i Ṭüsī, ed. by G. Schubert (Beirut: al-Shirka al-muttahida li l-tawzī', 1995), 15-46.

13 Șadr al-Dīn al-Qūnawī, Maktūb ākhar min al-Qūnawì yudāfi' fìhi 'an kitābihi Rashh al-bāl, in Annäherungen, ed. by G. Schubert, 131; translation by William C. Chittick in "Mysticism versus Philosophy in Earlier Islamic History: the al-Ṭūsī, al- Qūnawī Correspondence," Religious Studies 17 (1981), 87-104, esp. 102.

14 Muḥammad b. Ḥamza al-Fanārī, Miṣbāḥ al-uns, in Miftāḥ al-ghayb wa sharḥuh Miṣbāḥaluns, ed. by M. Khājavī (Tehran: Intishārāt-i mawlā, 1374), 10.9-10. 
of superiority of the Divine Science that its proofs, though mainly depend on unveiling (kashf) and experience (dhawq), comply with the truth of the rational reasoning. ${ }^{15}$ It seems therefore legitimate to infer that they found no harm in taking the logicians' theory of demonstrative science to apply it to their Divine Science, even if they did not want to explicitly call it "demonstrative science" and to acknowledge their debt to logicians in this respect.

\subsection{The Subject Matter of the Science}

As mentioned above, although Aristotle was the first to formulate the conditions that every discipline has to comply with in order to be regarded as an independent discipline of science, it was Avicenna who gave the theory its consummate form in the Islamic world. ${ }^{16}$ As will be seen, Qūnawī and Fanārī seem to have committed to Avicenna's theory in large part and now and then repeat the formulae from his well-known writings, particularly al-Ishärāt wa-ltanbih $\bar{a} t,{ }^{17}$ with some minor, but sometimes significant, modifications to align the theory to their own needs. Accordingly, Qūnawī holds that each scientific branch has a specific subject matter (mawd $\left.\bar{u}^{c}\right)$, principles (mabād $\left.\vec{\imath}\right)$ and problems (masẩil or mațālib). ${ }^{18}$ Commenting on this sentence, Fanārī adds that it is through their respective subject matter that sciences differ from each other in an essential manner; that is to say, the subject matter of a given discipline is its differentia. ${ }^{19}$ For Fanārī, each discipline deals with a multiplicity of entities, which are supposed to have a point of unity (jihat al-wahda) to bind them together. There are in fact two points of unity, one being essential, namely the subject matter of the discipline and the other accidental, namely its purpose. ${ }^{20}$

The subject matter of a given science, Qūnawī defines, is such that one investigates in that science its reality, and the states belonging and the accidents attaching to it in and of itself. He provides some examples of subject matters from different areas, such as existence (wujūd) as the subject of metaphysics,

15 Fanārī, Miṣbāḥ al-uns, 28.5-6.

16 Avicenna dealt with the issue in almost all of his texts on logic, but we find the most comprehensive exposition in his Kitāb al-burhān. See Ibn Sīnā, al-Burhān, II.6, 155-61. See also Ibn Sīnā, Kitāb al-najāt, ed. by M. Fakhrī (Beirut: Dār al-āfāq al-jadīda, 1982), 104-12; alIshārāt wa-l-tanbīhāt, ed. by S. Dunyā (Cairo: Dār al-macārif), vol. I, 474-8.

17 Ibn Sīnā, al-Ishārät, vol. I, 474-8.

18 Ṣadr al-Dīn al-Qūnawī, Miftāh al-ghayb wa sharḥuh Miṣbāh al-uns, ed. by M. Khājavī (Tehran: Intishārāt-i mawlā, 1374), 4.7-8. For the difference between these two terms, masā̄il and mațālib, see Eichner, "Al-Fārābī and Ibn Sīnā on 'Universal Science'," 75-6.

19 Fanārī, Miṣbāḥ al-uns, 39.7.

20 Fanārī, Sharh al-Īsāghüjī, in Tam kayıtlı Fenarive Kavli Ahmed (İstanbul: Salah Bilici, 1985), 3-4. 
but with the caveat of "according to one view ('alä ra'y)," and magnitude as that of geometry. ${ }^{21}$ Qūnawì's definition, though Avicennan in substance, ${ }^{22}$ has an addition to Avicenna's: the reality of the subject matter ('an haqiqatihi). Unlike Avicenna, who holds that only the essential accidents of the subject are inquired, Qunnawi claims that not only these but also the reality of the subject should be searched for in a given discipline. However, then what could Qūnawī have intended by inserting this phrase into the well-known Avicennan formula? By haqiqa of the subject, what did he mean? I think we should linger on these questions for a while, hoping that they can help us better understand Qunawì's probably most important contribution to the theory, but first I would like to mention Fanāri's explanations about the other, seemingly less complicated components of the definition.

The essential states of the subject matter, Fanāri comments, are the realities that only occur dependently on the reality of the thing. The essential accidents, on the other hand, are the realities that attach, perhaps through the mediation of the states and levels (marātib), ${ }^{23}$ to the reality of the thing. For Fanārī, the term 'essential' just mentioned as the attribute of both states and accidents signifies here that their entifications (ta'ayyunāt) are required by the essence of the thing itself and their subsistence (thubütuhā) in the thing depends only on the preparedness of the locus (i.e., the thing). Moreover, the essential accidents must be peculiar to, not more general than, the thing in this regard. In other words, 'walking,' for example, is not an essential accident of 'human', because 'human' is characterized by 'walking' only insofar it is an 'animal.' The subsistence of the accident of 'walking,' therefore, is not dependent on the existence of 'human.'24

As for the question of how to interpret Qūnawìs haqīqa in the definition above, it is almost evident that by inserting that phrase into the definition, Qūnawī must have meant to include the haqĩqa of the subject matter in the questions of the discipline, as suggested by his wording, "that whose reality is searched for." In fact, there are a limited number of scientific questions

21 Qūnawīs definition of the subject matter reads as follows: fa-l-maw fìhi 'an haquìqatihi wa-'an al-ậwāl al-mansūba ilayhi wa-l-umūr al-äriḍt lahu li-dhātihi (Qūnawī, Miftăh al-ghayb, 4.9-11). Note also that the subject of metaphysics according to Avicenna is the existent (al-mawjūd), not existence. See Ibn Sīnā, al-Shifä̀: al-Ilāhiyyāt, ed. by A. Anawātī \& S. Zāyed (Cairo: al-Hay’a al-āmma li-shu’ūn al-mațābi‘ al-amīriyya, 196o), vol. I, 13.12-3.

22 Cf. Ibn Sīnā, al-Burhān, II.6, 155.8-9; al-Ishārāt, vol. I, 474-5; al-Najāt, 106.

23 For an explanation of the term martaba (pl. marātib) in the Akbarian tradition, see William C. Chittick, The Sufi Path of Knowledge (Albany: suny Press, 1989), 47.

24 Fanārī, Miṣbāḥal-uns, 39.18-40.3. 
one could ask to investigate the haqiqa of the subject: (1) what-ness $(m \bar{a}),(2)$ whether-ness $(\mathrm{hal})$, and (3) why-ness (limā) questions. What-ness questions, that are meant to conceptualize the thing, have two types: (1a) that which asks about the meaning of a given term, or about what is intended by the term (for example, 'what is the void $[k h a l \bar{a}]$ ?'), and (1b) that which asks about what the quiddity of the thing is (for example, 'what is man?'). Similarly, whether-ness questions ask either (2a) whether the thing exists at all (absolute [muțlaq] or simple [basit $]$ whether) or ( $2 \mathrm{~b})$ whether the thing has certain characteristics signified by the predicate (qualified [muqayyad] or composite [murakkab] whether). Of these question types, (1a) comes first, and then (2a), ( $1 \mathrm{~b}),(2 \mathrm{~b})$, and finally (3). ${ }^{25}$ So, which one of these types of questions could Qūnawī have meant to ask in order to determine the haqiq $a$ of the subject? I would like now to focus the discussion on this question and to argue at the outset that we can dismiss questions (2b) and (3) from the list, because they are already implied by the expression 'the states belonging and the accidents attaching to it' in Qunawì's definition of the subject matter above, so there is no need to discuss them again in respect to the term haqiqa. We have therefore three alternatives at hand: (1a), (2a), and (1b). That is to say, we shall investigate whether haqiqa means here the nominal definition of the subject matter, its existence, or its real definition respectively.

In the hope of coming across a helpful hint, I shall first look at the senses in which Ibn 'Arabī and his followers use the term haquīqa. In his al-Futühăt al-makkiyya, for instance, Ibn 'Arabī defines haqiqqa as "that on which existence $(a l-w u j u \bar{d})$ depends with all the differences, similarities, and contrasts it has," ${ }^{26}$ placing it in contrast with or in relation to existence (wujüd). It is well known that in the philosophy of the Akbarian school, wujüd in the strict and real sense refers only to God, the Real (al-Haqq), and only metaphorically and relatively to things other than Him. According to Ibn 'Arabï's sentence just quoted, then, the Real is the haqiqa of all existents other than Him (which is why He is called "the Reality of Realities [Haqiqa al-haquāiq]") on the ground that only the Real has existence while the others are described as existent just because the Real lends them their shadowy existence according to His knowledge of them. ${ }^{27}$ This brings us to another sense of haqiqa, according to which

25 Ibn Sīnā, al-Burhān, I.5, 67. Cf. Ibn Sīnā, al-Najāt, 103-4; and al-Ishārāt, vol. I, 489-9o.

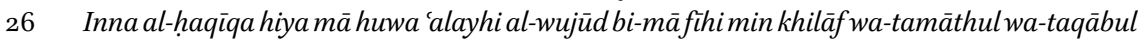
(Ibn 'Arabī, al-Futūhāat al-makkiyya [Cairo: Dār al-kutub al-'arabiyya al-kubrā, 1911], vol. II, $563)$.

27 William C. Chittick, The Self-Disclosure of God: Principles of Ibn al-Arabi’s Cosmology (Albany: suny Press, 1998), xix. 
God's knowledge is the haqiqa of the things. The eternal forms as the content of God's knowledge determine the actualization of the absolute existence in the phenomenal world and it is in this sense that they are the haqiqa of the concrete entities. ${ }^{28}$ Qunawī seems to refer to this meaning of haqĩ qa when he states that "the reality (haqiqa) of an existing thing is nothing but the relation of its entification in the knowledge of its Lord (nisbat ta'ayyunihi fi ilm rabbihi)." It is called in the Sufi terminology, he adds, "the fixed entity ('ayn thäbita)", and in the terminology of others "essence (mähiyya)," or "the non-existent known (ma'lüm ma'düm)." ${ }^{29}$ We can tentatively conclude that by featuring haqìqa in the definition of the subject, Qūnawi may have suggested that each scientific discipline should search for the essence, or real definition ( $1 b$ ), of its subject matter. Actually this conclusion is well in line with the comments on Qunawì's expression by his commentators, such as Fanārī, who interprets the haqiqqa at issue as "the quality of its manifestation in God's knowledge,"30 and Uthmān Faḍlì Atpazārī (d. 1691), who gives the examples of medicine and geometry, the first of which, he curiously claims, investigates the haqiqa of human body and the latter the haqiqa of magnitude, alongside their essential states and accidents. ${ }^{31}$ This interpretation of the term haqiq a, however, is problematic because, as will be seen when discussing the principles of sciences, Qunnawi features the definition of the subject matter among the principles of a science, as was pointed out by another Ottoman commentator of the Miftăh al-ghayb, Muhammad b. Quṭb al-Dīn Iznīqi (d. 148o). ${ }^{32}$ So, it would have been very odd on Qūnawı̀'s part if he had taken the definition of the subject both as a principle and as a problem of a science. But it can be put forth here that the definition Qunawì will count as one of the principles of a science is the nominal definition of the subject (1a), but he treats its real definition ( $1 \mathrm{~b})$, and presumably the establishment of its existence (2a), as objects of inquiry of the science.

28 See Toshihiko Izutsu, Sufism and Taoism: A Comparative Study of Key Philosophical Concepts (Berkeley \& Los Angeles: University of California Press, 1984), 159-91.

29 Qūnawī, Miftăh al-ghayb, 20.15-6. Cf. Fanārī's definition of the haqüqa of a thing as "the quality of its manifestation in God's knowledge" (Mișbāh al-uns, 39.9-10). For a discussion of the probable influence of Mu'tazilites on Ibn 'Arabī's ideas about the fixed entities, see Abū al-A'lā 'Afîfī, "al-A'yān al-thābita fì madhhab Ibn 'Arabī wa-l-ma'dūmāt fì madhhab al-Mu'tazila," in al-Kitāb al-tidhkārī Muhyī al-Dīn ibn 'Arabì fì l-dhikrā almiawiyya al-thāmina li-mülādih, ed. by I. Madkour (Cairo: Dār al-kutub al-'arabī, 1969), 209-20.

30 Fanārī, Miṣbāḥ al-uns, 39.9-10.

31 Uthmān Faḍlī Atpazārī, Miṣbāḥ al-qalb sharh Miftāḥ al-ghayb, Ms Süleymaniye Yazma Eser Kütüphanesi, Hacı Mahmut Efendi 2334, 3.16-7.

32 Muhammad b. Quṭb al-Dīn Iznīqī, Fatḥ Miftāḥ al-ghayb, ed. by A. Rāshidiniyā (Tehran: Intishārāt-i sokhan, 1395), 48. 
This complies with the idea that (1a) precedes all the other types of question, because one cannot talk about anything until one has an idea about what it is, or at least what it means as a name. This objection may make more sense in light of Fanārì's criticisms against logicians concerning their unnecessarily restrictive description of the subject matter. Hence, given that Qunnawī will take the definition of the subject matter among the principles of the science, we set aside option (1a), too, and focus our attention on the other two, (1b) and (2a).

From Qūnawīs definition of the subject matter, Fanārin infers some tacit objections against what he views as "the mistakes of the people of reflection" and moves on to discuss them as follows:

[T1] The first [of the logicians' mistakes is] their restriction of what is pursued (al-mabhüth 'anhu) to the states [of the subject matter], holding that $[\mathrm{A}]$ the reality of the subject matter of each science has to be proven in another science, because composite whether-ness questions (al-haliyya al-murakkaba) are derivative of simple ones (al-haliyya albasița). Proving the problems of the science is dependent on the establishment (thubüt) of the reality of the subject matter. If it [i.e., the reality of the subject matter] were to be proven in the problems, there would occur circularity. [B] This is because we do not grant the restriction of the problems [of a science] to the states [of its subject matter], especially in a science above which there is no science. ${ }^{33}$

Here Fanārī first $[\mathrm{A}]$ relates the view of logicians he is against and then [B] states that they (Fanārī and presumably Qūnawī) do not accept this view, without providing any counterargument or clear reason. But it seems clear that it is most probably Avicenna and his followers who are meant by Fanārī's epithet "the people of reflection," given the fact that Avicenna occasionally stated, as noted above, that "the subject matter is the thing whose essential accidents and states the art exclusively investigates." ${ }^{34}$

"The people of reflection," Fanārī relates, regard the objects of inquiry of sciences (al-mabhüth 'anhu) as solely consisting of the essential states and accidents of the subject matter on the ground that the composite whether-ness questions about the subject matter $(2 \mathrm{~b})$, which ask whether certain descriptions belong to the subject (and are of the form whether $S$ is $P$ or not $P$ ), require

33 Fanārī, Miṣbāḥ al-uns, 40.4-7.

34 Ibn Sīnā, al-Burhān, II.6, 155.8-9. 
the existence of the subject. In other words, it is only after positively answering the simple whether-ness question (2a) about the subject (S exists or does not exist) and granting that the subject exists that we can move on to ask whether certain characteristics are truly predicated of it. ${ }^{35}$ If we were to take both simple and composite whether-ness questions about the same subject as the problems of one and the same science, this would lead to clear circularity. After criticizing the logicians' position, Fanārī did not come up with any counterargument. Nor did he explain how to come over the alleged problem of circularity. ${ }^{36}$ But significantly, here Fanārī carries the discussion to the questions of existence, i.e. simple whether-ness (al-haliyya al-basița) questions (2a), and gives the impression that he interprets the term haqiqa in Qūnawìs definition of the subject matter as covering both the real definition and the existence of the thing, that is, the two options we still have at hand, ( $1 \mathrm{~b})$ and ( $2 a)$. We may safely conclude that for Fanārī, a given discipline aims to establish the existence of its subject matter as well as its real definition. In fact, he explicitly states later on in his Miṣbāh al-uns that although the conception of the subject matter belongs to the category of principles of the discipline, the research for its existence and whether-ness (haliyyatuhu, presumably meaning simple whether-ness) is one of its problems, or objects of inquiry, underlining once more the disagreement between their position and that of the majority of scholars (al-jumhür) on the issue. $^{37}$

Yet, once consulting Fanārì's other works to get more complete a picture of his position on the subject matter, one witnesses him embracing the position of the majority. In his commentary on İsāghüjü, for example, Fanārī says: "Logic is the science in which the essential accidents of conceptions and assents are investigated, $[\ldots]$ or the essential accidents of the secondary intelligibles $[\ldots] .{ }^{\prime \prime 3}$ Notice that there is no mention at all of the reality of conceptions, assents or secondary intelligibles, which are the subject matter of logic according to two

35 This is according to the well-known principle of derivativeness ( $q \bar{a}$ idat al-far iyya), which states that the subsistence of something in something else presumes the existence of that in which it subsists. For a thorough discussion of the principle, see 'Alī Kāshif alGhițā, Naqd al-ārā' al-manțiqiyya wa-ḥall mushkilātihā (Beirut: Mu’assasat al-nu'mān, 1382), vol. II, 352-68.

36 In fact, Fanārī's predecessor in the Akbarian tradition, Dāwūd al-Qayșarī (d. 1350), seems to disagree with both Qūnawī and Fanārī, when he states that the subject matter of a science is that whose essential accidents are investigated therein (Dāwūd al-Qayșarī, Risāla fi 'ilm al-tașawwuf, in al-Rasā̉il li-Dāwwūd al-Qayșarī, ed. by M. Bayrakdar [Kayseri: Kayseri büyükşehir belediyesi, 1997], 110).

37 Fanārī, Mișbāh al-uns, 149.1-3.

38 Fanārī, Sharh al-Īsāghūjī, 4. 
different positions. Moreover, in his Fușūlal-badā’ í, devoted to the principles of Islamic jurisprudence, he only speaks of the essential accidents of the subject matter of Islamic jurisprudence. ${ }^{39}$

We have so far found two seemingly inconsistent positions on the subject matter of sciences held by Fanārī. In his Miṣbāḥ al-uns, Fanārī is explicitly against the logicians' view that a science investigates only the essential accidents of its subject matter, and neither its existence nor its essence, a view he seems to embrace in his other works. In that case, could there be a way out of this apparent inconsistency for Fanārī? I think we can try to answer this question positively by interpreting in Fanārī's favor the emphasis he adds at the end of the passage in which he rejects the logicians' position particularly in the case of a science, which is the highest in the hierarchy of sciences. In doing so, Fanārī might have suggested that the highest science is an exception to the rule that no science can investigate its own subject matter. This is because it is not possible for the highest science, unlike the inferior ones, to obtain the definition of its subject from higher sciences, given the fact that there is no science above it. In fact, we have textual evidence in favor of this interpretation. In his Fuṣul albadā'ic, Fanārī states that the principles of any given discipline are investigated in a higher science, but when it comes to the highest science, they will necessarily be investigated in the science itself. ${ }^{40}$ Then, it should search for its own subject matter, or more precisely whether the subject matter exists at all and what are its essential constituents, according to Fanārì's passage above, as well as its essential accidents. However, is this charitable reading of Fanārī regarding the highest science able to offer a solution to the alleged problem of circularity?

It might be, and in fact was, suggested that circularity is not an inevitable dead-end of the idea that a science can examine its own subject matter. ${ }^{41}$ This is because the science has two groups of questions, the former of which is related to the essence and existence of the subject matter, while the latter depends on the former and is related to the essential accidents of the subject matter. ${ }^{42}$ This position may be defended also on the ground that classifications of sciences

39 Fanārī, Fușūl al-badā̉ic fì uṣūl al-sharā̉ic, ed. by M.Ḥ. Ismāīil (Beirut: Dār al-kutub al'ilmiyya, 2006), vol. I, 9.

40 Fanārī, Fuṣūl al-badā'ic', I, 9. r.

41 This position was embraced by Ibn Khaldūn (d. 1406), the renowned Muslim historian and philosopher of fourteenth-century Andalusia, in the case of his 'ilm 'umrān: "It is not the responsibility of the men of science to prove the subject matter in that science, but it is not impossible either" ('Abd al-Rahmmān b. Khaldūn, al-Muqaddima, ed. by 'A.M. alDarwīsh [Damascus: Dār ya'rub, 2004], vol. I, 138).

42 For a view along these lines, see Mīrzā Hāshim al-Ashkūrī’s glosses on Fanārì's comments, in Fanārī, Miṣbāḥ al-uns, 40, fn. 2. 
are put forward only to facilitate scientific research by collecting innumerable things under certain titles that are finite in number and easy to handle. Hence, they are somewhat conventional. It is evident, however, that Fanārì's reading of Qunawì's views of the subject matter of sciences was against the established practise of Islamic scholarship, and Qūnawi therefore became subject to different interpretations by the commentators of the Akbarian school. Muhammad Iznīqī, for example, did not agree with Fanārī and tried to smooth out Qūnawì's statement by interpreting his addition "the reality of the thing" as "the states that adhere to its essence, or reality." On this interpretation, he claims, Qūnawìs statement comes to an agreement with the position of the logicians. ${ }^{43}$

Another, maybe more crucial, challenge for Fanārī's interpretation was the fact that it was at odds with Avicenna's position on the issue since it inserted haqiqa in the definition of the subject matter. Avicenna is clear that the existence and definitions of the subject matter and its parts should be taken for granted at the beginning of scientific research, and it is impossible for a discipline to prove its subject matter. For, he says, "if its essence was not understood [at the very beginning], then it would be impossible to find out any of its features." ${ }^{4}$ Thus, for Avicenna, the definitions of the subject matter and its parts are among principles of the science, but not its problems.

To conclude, pace the prevalent position of Muslim scholars after Avicenna, Qūnawī and Fanārī seem to embrace the idea that a given discipline should try to establish the existence of its subject matter (2a) and discover its essential constituents $(\mathrm{lb})$ as well as its essential accidents.

\subsection{The Principles of the Science}

The second element of a science is, for Qūnawī, its principles which function as the bases upon which the deductions of the science are built, being either conceptions or assents in keeping with Avicenna's famous distinction between the two:

[T2] The principles are either conceptions or assents. As for conceptions, they are definitions provided for the subject matter of the science, or the art in which it is investigated, or its [i.e., the subject matter's] ramifications ( furü'uhu), or details, or parts, or accidents. As for the assents, they are premises upon which this science is built and they, together with the definitions, are called 'assumptions (al-awd $\left.\bar{a}^{c}\right)$,' among which there are

43 Iznīqī, Fatḥ Miftāḥ al-ghayb, 47-8.

44 Ibn Sīnā, al-Burhān, I.5, 70.15; al-Ilāhiyyāt, I, 8.16-7; 13.10-1. 
certain and granted propositions due to confidence in, or good opinion (husn al-zann) about, the reporter. They are presented at the beginning of that science and called 'posited principles (al-ușūl al-mawdū'a)' [...] among which there are those granted temporarily until they are proven in another place, although the hearer and the disciple have doubts in themselves until they are explained to them in the following by means of either rational or divine, natural ( fitrī) demonstration. They are called 'postulates (muṣādarāt). ${ }^{45}$

While glossing these remarks of Qūnawī, which suggest strong parallelism with Avicenna's theory, Fanārī opines that these premises function as middle terms for the problems (masäill) of the science in terms of both assent and existence. He gives some examples for these principles. For him, for example, 'every created perfection exists in its creator in the most complete form' is a self-evident proposition, while 'God does not do injustice, even so little as an atom's weight,' taken from a Quranic verse, is a posited principle inasmuch as human reason readily admits that its contradictory is also possible, on the ground that the proprietor has an absolute authority over his property. The postulates, Fanārī says, are called muṣādarāt due to the fact that they are experiential judgements, that is, they are up to personal insights and religious, spiritual experience. Even in the rational sciences, he claims, there should be a difference between novices and experts, and beginners have to imitate experts until they experience and taste the same reality. ${ }^{46}$

To turn once again to the discussion above concerning the subject matter of the science in light of the passage, it is noteworthy that Qunnawi mentioned the definition of the subject matter and its parts among the principles of the discipline. Moreover, Fanārī notes that the definitions of the key terms should be provided here in the best possible way. In other words, their real definition should be given if possible, but if not, then at least their description or nominal definition, because these terms are all in turn parts of the problems, and one needs to have their conception (tașawwur) in mind before making a judgement about the problems. ${ }^{47}$ So, we should either take the definitions in the passage as only nominal ones (1a) or risk to face some troublesome possibilities, such as that Qūnawi took the real definition of the subject $(\mathrm{lb})$ as a pre-given principle, but left the research concerning its existence (2a) among the questions of the science. This, however, is impossible due to the fact that (2a) questions always

45 Qūnawī, Miftāḥ al-ghayb, 4.12-5.5. Cf. Ibn Sīnā, al-Ishārāt, vol. I, 476-7.

46 Fanārī, Miṣbāḥ al-uns, 42.11-43.8.

47 Fanārī, Miṣbāḥ al-uns, 41.7-10. 
precede $(1 b)$ questions, which is to say one cannot inquire into the real definition of a thing without ascertaining its existence. An alternative but equally troublesome possibility is that Qunawi meant by 'definition' in the passage the real definition of the subject, taking for granted its existence at the very beginning, but in that case he would inevitably be faced with the question why then he mentioned haqiqa as an object of inquiry as we have seen above. To avoid these impossibilities, I would like to keep my surmise that Qūnawī took (lb) and (2a) questions concerning the subject matter as problems (masä ì or mațälib) of the discipline, still expecting to find some clues about that in the next chapter.

\subsection{The Problems of the Science}

Each scientific discipline aims to investigate whether certain propositions or their contradictories are true, propositions which are called "problems" 48 of the discipline. Regarding this third element of the constitution of sciences, Qunawi briefly expresses his ideas as follows:

[T3]As for the problems (masǟil), they are the quaesita (mațālib), for which demonstration is pursued and whose proofs are required of the interlocutor. They are either the roots $(u s ̦ u ̈ l)$ comprehensive of [all] that which the science includes, like genera in relation to what falls under them, or the ramifications $\left(f u r \bar{u}^{c}\right)$ under the roots, like species, or species of species. When the roots and origins (ummahāt) and their properties are known and explained, then also the relation of the ramifications to them and the quality of their dependence on them is known, as well as their inclusion by them. ${ }^{49}$

The kind of demonstration to be used in the proof of the problems, Fanārī comments, may be rational (nazarī) as well as divine (ilähī) and dispositional ( fitri $\bar{c}) \cdot{ }^{50}$ Being propositions, the problems have two components: the subject and the predicate. As mentioned above, the genus that is the subject matter

48 There is a bunch of terms in the nomenclature of Muslim scholars to refer different aspects of the scientific problems, such as 'objects of inquiry (mabāhith)' (because scientific inquiry is directed at them), 'problems (masāill)' (because they are what is asked about), 'quaesita (mațālib)' (because they are sought after), and 'conclusions (natầij)' (because they are derived from premises); see Quṭb al-Dīn al-Rāzī, Sharh al-Mațāli', ed. by U. al-Sāeīīi (Qum: Dhawi'l-qurbā, 1433 HSh), vol. I, 84; and Iznīqī, Fatḥ Miftāḥ al-ghayb, 56 .

49 Qūnawī, Miftāh al-ghayb, 5.8-11.

50 Fanārī, Miṣbāḥ al-uns, 43.9-10. 
of the discipline, or its species may occur in the position of the subject of the problem, as Qūnawi notes in this passage. ${ }^{51}$ Predicates, on the other hand, consist of the essential accidents of the subject term on the condition that they should not be more general than the subject matter of the science.

Considering Qūnawī's insertion of the term haqĩqa into Avicenna's definition of the subject matter of any given discipline and Fanārīs insistence, defending the former's position, that they did not accept the logicians' confinement of objects of research to the essential accidents of the subject matter, we were in anticipation of finding some new problems in their exposition related to the real definition ( $1 \mathrm{~b})$ and the existence of the subject matter (2a). This is because if the haqiga of the subject is something that science must investigate (yubhathu 'anhu), then some of the scientific questions must inquire into its existence or definition. Neither Qūnawī nor Fanārī, however, says something to meet these anticipations, nor does either go beyond the standard Avicennan account of the scientific problems. However, in the next chapter devoted to the application of this theory to the Divine Science, we will more clearly ascertain that they take discussions on (2a), but not ( $1 \mathrm{~b}$ ), among the problems of the Divine Science.

Arguably, the most significant aspect of Qūnawì's and Fanārìs account of Sufism is their reworking it into a new scientific setting by applying the theory of science that has just been explained to tașawwuf, unanimously declaring that Divine Science has a specific subject matter, principles and problems. In this chapter, we will discuss Qūnawì's and Fanārì's representation of tașawwuf, or Divine Science, as a demonstrative discipline.

\subsection{The Subject Matter of Divine Science}

After emphasizing that it is a religious (shar $\tilde{\imath})$ science, Fanārī defines Divine Science, or the science of realities ('ilm al-haqāंiq), as "the science concerning God (al-ilm bi-llāh al-Haqq), the Exalted Reality, in terms of His relation to the creatures and the emanation of the universe from Him, according to the measure of human capacity (bi-hasab al-țāqa al-bashariyya)."52 The subject

51 For more details on the subject and predicate of problem propositions, see Ibn Sīnā, alNajāt, 106.

$5^{2}$ For Fanārī, it is important to add the last note, "according to the measure of human capacity," on account of the fact that there are some aspects of the science of realities which are 
matter peculiar to Divine Science, Qūnawī declares, is Real Existence (wujū d alHaqq). ${ }^{53}$ But Real Existence, according to Fanārī, in terms of His reality (haqìqa) is ineffable and by no means a subject of rational or imaginary investigation. It is, therefore, only in terms of His relation to the creatures and emanation of the universe from Him that Real Existence is the subject matter of Divine Science. ${ }^{54}$

As noted above, Qūnawì's and Fanārìs position that the subject matter of a scientific discipline consists not only of the essential accidents of the subject but also its reality itself raises an internal issue here for them. For, on this reading of the subject matter, Divine Science will have to investigate the existence and real definition of Real Existence, but Fanārī has just explicitly ruled out the possibility of providing a real definition of Real Existence on the ground that $\mathrm{He}$ is necessarily beyond all attempts to fathom His essence. Thus, we have no hope of obtaining the real definition of the Real, but Fanārī is clear about the point that the discussions concerning the two issues, namely the conception and the existence of the subject matter, are to be handled among the problems of Divine Science, although philosophers treat them as pre-given principles of the science: "It is appropriate in the method of verification to explain here the conception of Real Existence, which is the subject matter, and [to make] reference to its whether-ness (ilä haliyyatihì), because it

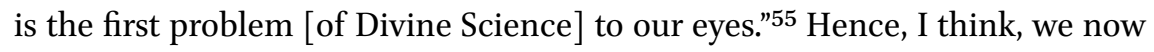
have an answer to our problem above concerning the status of (1b) and (2a) questions in Divine Science. Fanārī avoids the former of these two questions, claiming that Real Existence cannot be defined, but he tries his best to prove His existence, or more precisely, the necessity of His existence. That is to say, he regards the task of proving His existence as one of the problems of Divine Science.

Now leaving Fanārîs arguments on the necessary existence of the Real to the chapter of the paper on the problems of Divine Science, I would like to discuss here his account as to what Real Existence is. The first and foremost point both Qūnawī and Fanārī emphasize is the identity of Real or Absolute Existence with God: "Know that the Real (al-Haqq) [i.e. God] is Absolute Existence

eternally unknown to human beings (Fanārī, Miṣbāḥ al-uns, 44.2-3; see also Qūnawī, Miftāh al-ghayb, 6.6). For a different definition of Divine Science, see al-Qayșarī, Risāla fì 'ilm al-tasawwuf, 110-1.

53 Qūnawī, Miftāhal al-ghayb, 6.2.

54 Fanārī, Miṣbāhạ al-uns, 44.4-5.

55 Fanārī, Miṣbāḥ al-uns, 149·3-5. 
(al-wujüd al-mahd d), within which there is no differentiation at all." ${ }^{n 6}$ The Real, for Qunawī, is one in the real sense of the term and not in the sense that one conceptualizes multiplicity as His opposite. Thus, attributing oneness to Him is just for the sake of magnifying and sanctifying Him. Absolute Existence, Fanārī explains, is the existence, within which no limitation, even the limitation of absoluteness, is taken into consideration, and which is pure of all considerations and limitations. ${ }^{57}$ Qunawī, on the other hand, feels the need to make the clarification that the term wujüd is not a real name proper to the Real, but an attribute of His, which is identical to His essence, because His name is identical to His attribute and His attribute to His essence. ${ }^{58}$

Fanārī, however, devotes a number of sections in his Miṣbāh al-uns to proving Qūnawì's identification of the Real, or the Necessary Existent, to Absolute Existence through five demonstrations. I will not delve into these demonstrations in order not to wander away from our main subject, but here I would like to deal with Qūnawī's and Fanārìs account of the subject matter of Divine Science, by way of a comparison with Avicenna's theory of the subject of metaphysics. At the very beginning of the metaphysics of his Shifä (I.1), where he discusses and refutes the alternative views on the subject matter of metaphysics, Avicenna states that God's existence cannot be the subject matter of this science, but only one of its problems, due to the fact that the existence of the subject matter of any science is taken for granted in that science so that its essential accidents can be sought after. But if we take God's existence for granted in metaphysics, there follow these impossibilities:

Either (a) God's existence is proven in another science, or (b) it is proven nowhere.

Not (a), because none of the other sciences (i.e., ethics, physics, mathematics or logic) undertakes the task of proving God's existence.

Not (b) either, because in this case God's existence is either (b1) selfevident, or (b2) not self-evident but impossible to be proven through rational reflection.

Not (b1), because it is not self-evident.

56 Qūnawī, Miftāḥ al-ghayb, 19.10.

57 Fanārī, Miṣbāḥ al-uns, 150.7-10.

58 Qūnawī, Miftăh al-ghayb, 22.9-10. To avoid a confusion, it may be helpful to underline here a distinction the two Sufis draw between Absolute Existence, identical with the Real as explained, and general existence ( $a l$-wujūd al-ämm), which is the first thing emanating from the Real and is identified by the Sufis with the First Intellect of Muslim philosophers. See, e.g., Qūnawī, al-As'ila, in Annäherungen, ed. by G. Schubert, 6o; and Fanārī, Miṣbāh al-uns, 92.3-7, 97.11 et passim. 
Not (b2), because it is nonsense to take something for granted for which there is rational proof.

Therefore, God's existence must be proven in metaphysics as one of its problems. ${ }^{59}$

After rejecting the other alternatives, Avicenna reaches the conclusion that the subject matter of metaphysics is the existent inasmuch as it is existent (al-mawjüd bi-mā huwa mawjūd), and thus metaphysics seeks after the things accompanying the existent, inasmuch as it is existent. ${ }^{60}$

Qūnawī and Fanārī, however, critically approach Avicenna's theory of metaphysics and do not accept that its subject matter is the existent qua existent, ${ }^{61}$ but they agree with him that God's existence, or Real and Absolute Existence, is not self-evident and is therefore in need of proof, and that metaphysics is expected to prove it as one of its problems, notwithstanding their disagreement with Avicenna who would not concede the identification of God with absolute existence.

\subsection{The Principles of Divine Science}

The principles of Divine Science, according to Qūnawī, are the principles of realities that necessarily follow from the Real, that is, His essential names (asmä al-dhät). The properties of some divine names become manifest in the universe, by means of which alone God is known. The properties of the names are either seen from behind the veil of effects by obedient gnostics (al-'ârifin min al-abrār) or perceived through unveiling and witnessing without any veil or medium by the intimate and the perfect (al-muqarrabin wa-l-kummal). The effects of some other divine names may not be manifest at all, as God keeps them for Himself. ${ }^{62}$ After noting that divine names play the role of the middle term in syllogistics in terms of both assent and existence, in a manner reminiscent of Avicenna's differentiation between factual and causal demonstration, Fanārī respectively explains the distinction between the different ways of knowledge of the gnostic ('ärif) on the one hand and of the perfect (kämil) on the other. ${ }^{63}$ For him, gnostics infer from effects to their causes, whereas perfect men follow the reverse way, that is, from causes to their effects. ${ }^{64}$

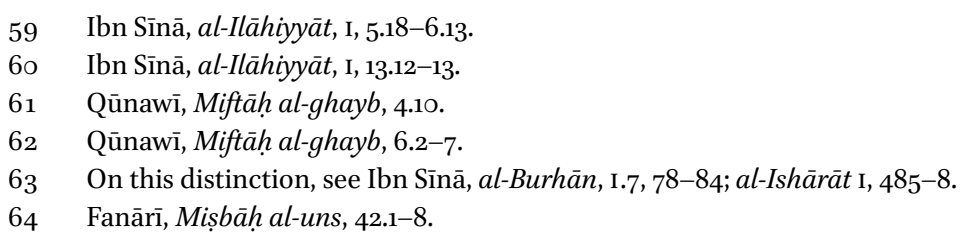


Fanārī then comes up with a hypothetical question as to how it could be possible for the principles of Divine Science to be known by those who are neither perfect men nor gnostics, if the principles of Divine Science are known only by the members of those two groups and the solutions of the problems depend upon the principles. He answers this question, commenting on Qūnawì's remarks, as follows:

[T4] We say: [The initiate, who is neither a perfect man nor a gnostic yet] takes all of them [i.e., the principles] as granted premises (musallama), as mentioned above, from the gnostic who has already verified them (almutahaqqiq bihā), that is, [who] has become a mirror of them without straining his mind, until it becomes evident for him [i.e., the initiate] why it is true either by means of reasoning, if it becomes available for the reporter gnostic (al-ärif al-mukhbir) or the property of his state, taste or station entails it, or by means of the verification of one who has heard (alsāmic) about the truth of it through something, which he finds in himself given by God, and in which he does not need an extrinsic cause, such as syllogisms, premises, etc. [...]. ${ }^{65}$

In this telling passage, we find significant hints concerning how Qūnawī and Fanārī try to implement logic in theory of science in such a manner, so to speak, that logic constitutes the form of Sufi content. They take some logical and formal elements in particular from philosophers, especially Avicenna, and extend to them a role to play in their spiritual system, a role that is mainly related to the deduction of problems from the principles of Divine Science. The idea that, for example, some principles of science can be taken for granted until they are found out by the learner, as we saw above, is taken from logic. The procedures of learning, though they also involve rational reasoning and discursive thinking to a certain extent, do usually belong to the Sufi view point and theory of knowledge. ${ }^{66}$ To mention an example of many occasions where Fanārī appeals

65 Fanārī, Miṣbāḥ al-uns, 48.7-11. Cf. Qūnawī, Miftāḥ al-ghayb, 7.2-6.

66 At this point, Iznīqì's remarks on the difference between tașawwuf, kalām and falsafa are significant. According to him, these scientific disciplines share the same subject matter, but they differ from each other by virtue of their respective foundation, or source of knowledge. Kalām works on a religious basis ( qānūn al-Islām), but falsafa carries out its research on a rational basis ( qānūn al-'aql), whether it is in line with Islam or not, and according to rational opinion and reflective understanding. Tașawwuf, however, depends on unveiling and inspiration; therefore, it does not depart from compliance with the commands of God and His prophet. See Iznīqī, Fath Miftāh al-ghayb, $5^{6}$. 
to logical rules to prove certain principles of Divine science, he makes use of logical conversion rules to show how the principle, 'whenever a cause becomes one, the effects also become one as well,' validly follows from the principle, 'whenever effects multiply, the cause also multiplies.' ${ }^{67}$

Qūnawī also offers a number of general principles that will function as the principles of Divine science, as we will be discussing shortly.

\subsection{The Problems of Divine Science}

As for the third element of Divine Science, its problems (masāil or mațälib) are what is made evident through its principles, namely the names of divine essence, and what follows them, like the names of divine attributes and divine

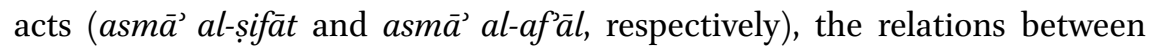
them, etc. But according to Qūnawī, all of these end up in two main problems of Divine Science: knowledge of the mutual relationship between God and the universe, and knowledge of that which is knowable and that which is not. ${ }^{68}$

As mentioned above, both Qūnawī and Fanārī regard proving the reality of Real or Absolute Existence as one of the objects of inquiry for Divine Science, and therefore Fanārī tries his best to show, contra some theologians and philosophers, that Absolute Existence is not only a mental concept. For him, among theologians and philosophers, there are opponents of the idea that the reality of the Real is nothing but Absolute Existence and they have raised several doubts about it, which were bound together and endorsed by Taftāzānī. ${ }^{69}$ It is evident that Fanārī here refers to the objections raised by the famous fourteenth-century theologian Sacd al-Dīn Mas'ūd al-Taftāzānī (d. 139o) in his Sharh al-Maqāsid, a summa of philosophical theology. Taftāzānī maintains that some philosophers and Sufis held the position that the reality of the Necessary Existent is Absolute Existence, the falsity of which, he says, "is too obvious to hide and too manifold to count."70 In one of his critiques, he says there is an agreement among the hukamä that absolute existence is one of the secondary intelligibles (al-ma'qūlāt al-thāniya $)^{71}$ and mind-dependent meanings

\footnotetext{
67 Fanārī, Miṣbāḥ al-uns, 92.1-2.

68 Qūnawī, Miftāḥ al-ghayb, 6.10-3; Fanārī, Miṣbāḥ al-uns, 48.1-4.

69 Fanārī, Mișbāḥ al-uns, 159.9-10.

70 Sacd al-Dīn Mašūù al-Taftāzānī, Sharh al-Maqāsid, ed. by 'A. 'Umayra (Beirut: 'Ālam alkutub, 1998), vol. I, 336.

71 For Avicenna, secondary intelligibles depend on primary intelligibles and have only intellectual existence (Ibn Sīnā, al-Ilāhiyyāt I, 10.16-11.1). For a comprehensive analysis of secondary intelligibles, see Abdulhamid I. Sabra, "Avicenna on the Subject Matter of Logic," The Journal of Philosophy 77 (1980), 746-64.
} 
(al-umür al-itibäriyya), ${ }^{72}$ which have no realization in the external world. ${ }^{73}$ Philosophers and theologians take 'existence' as a secondary intelligible due to the fact that it depends on primary intelligibles, like 'human,' 'horse,' and 'wood,' which have individual referents outside the mind. Secondary intelligibles, however, do not have any referent in the external world; there is no such a thing outside as 'existence,' or 'thing. ${ }^{.74}$ There are only individuals with some accidents and attachments that can by no means be absolute and free from individuating limitations and determinations. But it is only possible for the human intellect to consider things in themselves or absolutely. Thus, according to Taftāzānī, identifying God with absolute existence means that He has only mental existence and is devoid of external reality, which is unacceptable to any Muslim theologian.

In his response to this critique, Fanārī states that the truth requires the existence of natural universals in the external world due to the fact that one of their two divisions, that is, the mixed one (al-makhlūt ), exists externally. ${ }^{75}$ To better understand Fanārī's answer, we must elaborate on Avicenna's two distinctions related to universal concepts. In his Shifä̀ al-Madkhal I.12 and al-Ilähiyyāt V.2, Avicenna draws a distinction between natural $(t a b i \bar{\imath} \tau)$, mental ('aqlī) and logical (manțiq $\overline{)}$ universals. According to this distinction, the term 'animal' for instance has a meaning in itself independent of whether it is existent in the mental or extramental world, whether it is universal or particular, etc. 'Animal,' taken insofar as it is animal, is a natural universal according to Avicenna. When we consider that 'animal' is truly predicated of many things, we understand that it is a universal concept and hence attach the meaning of universality to it in the mind. Universality itself, which renders the concept predicable of more than one instance, is a logical universal that exists only in the mind. When we consider, on the other hand, the whole 'the universal animal,' we obtain a mental universal, which exists only in the mind. ${ }^{76}$

Another division of Avicenna's that is also relevant here is between three considerations of essences, or the natural universals of the previous classification. According to this distinction, an essence is taken into consideration

72 For an Akbarian counterargument against the idea that existence is ítibārī, see Dāwūd alQayṣarī, Sharh Fuṣūṣ al-ḥikam, ed. by H.H.Ḥ. al-Āmulī (Qum: Bustān-i kitāb, 1382), vol. I, 37, 46.

73 Taftāzānī, Sharh al-Maqāsid, vol. I, 337.

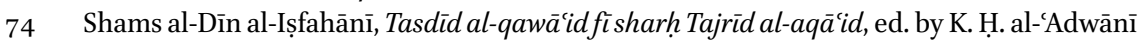
(Kuwait: Dār al-dịā̄', 2012), vol. I, 315.

75 Fanārī, Miṣbāh al al-uns, 16o.1-2.

76 On the details of the distinction, see Ibn Sīnā, al-Shifä̀, al-Manțiq I: al-Madkhāl, ed. by A. Anawātī et al. (Cairo: al-Mațbáa al-amīriyya, 1952), 65-72; al-Ilāhiyyāt, I, 207-12. 
(1) in terms of its extra-mental existence through the existence of its particular referents, or (2) in terms of its mental existence, which is abstracted from its real individual referents, or (3) absolutely, without consideration of either kind of existence. ${ }^{77}$ Although Avicenna did not have particular names for these three considerations of essences, they have been called by later logicians as mixed (makhlüța), abstract (mujarrada) and absolute (muțlaqa) essences, respectively. ${ }^{78}$

If we turn to Fanārī's response in light of these explanations, we see that he denies that Absolute Existence, identified with the Real by the Sufis, is a secondary intelligible. He, like some other members of the Akbarian school, applies Avicenna's classification of essences to the concept of existence and maintains that Absolute Existence is a universal nature (haqiqqa), or more precisely, a natural universal. ${ }^{79}$ For him, existence has three aspects or considerations: (1) absolute existence, which is taken unconditionally (al-ma'khüdh bi-lā sharț), (2) mixed existence, which is positively conditioned (al-ma'khūdh bi-shart shay'), and (3) abstract existence, which is negatively conditioned (al-ma'khūdh bi-shart lā shay') ${ }^{80}$ Absolute Existence is identical to the Real according to Fanārī, and may in turn be considered in two ways, taken in itself and taken as related to possible things. ${ }^{81}$ Absolute Existence has real and external existence due to the fact that one of its divisions, namely the mixed exis-

77 On this, see for example Ibn Sīnā, al-Ishārāt, vol. I, 154.

78 See for example, 'Aḍud al-Dīn 'Abd al-Raḥmān al-İjī, al-Mawāqif fì 'ilm al-kalām (Beirut: 'Ālam al-kutub), 6 o.

79 As far as I have been able to ascertain, this idea occurs for the first time in Qayṣarì's work in an occasion where he answers a hypothetical objection that existence, insofar as it is such (min haythu huwa hwwa), is a natural universal and natural universals exist only through the existence of their particulars. Qayșarī does not reject the minor premise of this syllogism, namely that existence is a natural universal, but he does reject the major one, stating that existence is not like other natural universals in this regard. See Qayṣarī, Sharh Fuṣūṣalhikam, I, 39-40. The view of existence as a natural universal also comes up in Mullā Jāmī's and al-Sayyid al-Sharîf al-Jurjānī's treatises on the unity of existence. For the Arabic text and English translation of the former, see Nicholas Heer, "Al- Jāmī's Treatise on Existence," in Islamic Philosophical Theology, ed. by P. Morewedge (Albany, NY: SU NY Press, 1979), 22356 , and for the edited text of the latter, with an introduction and commentary, see Sa'īd Fūda, Fatḥ al-wadūd bi-sharh risāla al-Sayyid al-Sharīf al-Jurjānī fi waḥdat al-wujūd (n.p.: Manshūrāt al-aṣlayn, 2011).

8o For an in-depth analysis of this doctrine, see Toshihiko Izutsu, The Concept and Reality of Existence (Tokyo: The Keio Institute of Cultural and Linguistic Studies, 1971), particularly 49-55; and "The Problem of Quiddity and Natural Universal in Islamic Metaphysics," Dirāsāt falsafiyya muhdāt ilā l-duktūr Ibrāhìm Madkūr, ed. U. Amīn (Cairo: al-Hay’a almișriyya al-āmma li-l-kitāb, 1974), 131-77.

81 Fanārī, Miṣbāḥ al-uns, 210.19-211.3. 
tence, exists outside the mind, as has been accepted by most philosophers and theologians concerning mixed quiddities. ${ }^{82}$ Regarding Absolute Existence as a natural universal, Fanārī will still have to struggle with the non-realist positions on the existence of universals in Islamic thought, and to prove the external existence of Real or Absolute Existence against the opponents of the doctrine of wahdat al-wujūd. ${ }^{83}$

Alongside these three necessary elements, Qūnawī thinks, the sciences should also have a measure (mi'yār) to distinguish the true from the false therein, and the highest science (al-ilm al-ilähi $)$ is not an exception to this rule. Then what is its criterion? In the following chapter, I will discuss what Qunnawi and Fanārī meant by the criterion of Divine Science and why they felt the need to bring it up at all.

\section{$4 \quad$ The Sufis' Criterion of Truth}

By now, I hope, it has become clear that Qūnawì and Fanārī tried to present tașawwuf as a formal discipline built on the mystical understanding of the Islamic foundations, a discipline, therefore, which has logical and demonstrative form and mystical and Islamic content. But Qūnawī would have felt uncomfortable with the emphasis made on logic in this sentence, because, he claims, Divine Science has its own body of criteria, alongside its subject matter, principles and problems, to distinguish what is valid from invalid in every part of the science. He puts this view into words as follows:

[T5] Also each science has a measure by means of which the sound [part] (sahịh) of what is peculiar to it [i.e., science] is known from the ill (saqimihi) and the false from the true, like grammar in the science of expression ('ilmal-ibāra), prosody in the knowledge of meters and rhymes of poetry,

82 On the details of the debate, see Yuki Nakanishi, "Post-Avicennian Controversy over the Problem of Universals: Sa'daddīn at-Taftāzānī (d. 1389/9o) and Šamsaddīn al-Fanārī (d. 1431) on the Reality of Existence," in Islamic Philosophy from the 12th to the 14th Century, ed. by A. Al Ghouz (Göttingen: Bonn University Press, 2018), 353-71. For a comprehensive study on the discussions concerning universals in Islamic thought, see Muhammad U. Faruque, "Mullā Șadrā on the Problem of Natural Universals," Arabic Sciences and Philosophy 27/2 (2017): 269-302.

83 See Fanārī, Miṣbāḥ al-uns, 105-6. Fanārī does not mention explicitly, as far as I can see, the distinction between the mental concept of Absolute Existence and its reality, the former of which is universal while the latter particular and identical to God. For the distinction, see Heer, "Al- Jāmī's Treatise on Existence," 226, 238. 
logic in the rational sciences [...]. As the superiority of each science is contingent upon [the superiority of] its subject and the related things, Divine Science is the most superior, because of the superiority of its subject, which is the Real. Thus, the necessity of knowing its criteria and acquiring its canonic principles and rules is more discernible. ${ }^{84}$

Following Qūnawī, Fanārī acknowledges that Divine Science's need of a criterion is all the more obvious, given that it is the highest science and that every science needs a criterion. Reading this passage of Qūnawī together with Fanārî's comments on it, one gets the impression that they will offer a body of rules or procedures that is able to function as a tool for both acquiring new knowledge and testing the validity of any inference within science. This is so because Qūnawī explicitly mentions logic for rational sciences, prosody for the art of poetry and grammar for the linguistic arts, and places the criteria of Divine Science in contrast with them. Moreover, they use in this context terms,

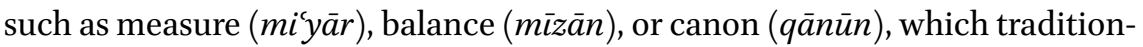
ally were shorthand for logic in the Arabic nomenclature of philosophers as well as other Muslim scholars, ${ }^{85}$ including the two Sufis themselves in many other contexts. ${ }^{86}$ They also reject any real connection with, let alone dependence on, philosophers, theologians and logicians, even in terms of technical vocabulary. ${ }^{87}$ For Qunnawī, everything that gives the impression of participation with the "scholars of superficiality ('ulama $\bar{a}^{3}$ al-rusüm)" in terms of utterances and vocabulary is misleading and should not be taken to mean that Sufis are restricted to this terminology. But this participation, he claims, suggests either that this terminology is relatively more appropriate in expressing what the utterer has in mind or that the station (maquam) in which the utterer is speaking is so comprehensive that it covers both what the veiled (mahjūb) scholar attains

84 Qūnawī, Miftāh al-ghayb, 7·7-12. In his examples of grammar and prosody, Qūnawī seems to be influenced by Arabic logicians, who often used these to justify logic and explain its necessity. See, for example, al-Fārābī, Ihṣ̂ă' al-ulūm, ed. by 'A. Abū Malḥam (Beirut: Dār wa-maktaba al-hilāl, 1996), 28; Ibn Sīnā, al-Madkhāl, 20.

85 The titles of Ghazālī's books on logic are revealing enough in this respect: Mi'yär al-ilm (The Measure of Knowledge), Mihakk al-nazar (The Touchstone of Reasoning) and al-Qisțās al-mustaqim (The Just Balance).

86 Fanārī usually makes use of the term mizzān instead of manțiq when referring to logic. See, for example, Mișbāh al-uns, 32.6; 34.13; 48.12.

87 In contradistinction to this explicit rejection is the fact that the writings of Qūnawī, and especially Fanārī, are replete with examples of logical inference. Moreover, they both claim to corroborate their mystical knowledge with conclusions acquired through rational thinking and reflection, or to reconcile between these two kinds of knowledge. See Qūnawī, Maktūb ākhar min al-Qūnawì̄, 131-2; and Fanārī, Miṣbāḥ al-uns, 10.9-10. 
through his reflection and what is given to the Sufi who approaches the object of knowledge through his heart (mutawajjih bi-qalbihi). Nonetheless, there is a radical difference between the Sufi and the veiled; while the former takes that meaning without his own effort through unveiling and witnessing in his pure heart, free from all doubts, the latter takes it from behind the veil of human reasoning, violating its purity. Actually, therefore, there are two distinct meanings behind one and the same term used by both the Sufi and the veiled scholar. ${ }^{88}$ Thus, I think we can safely conclude for now that Qunnawi will come up with a new logic or methodology peculiar to Divine Science.

Another, perhaps more challenging, problem that Qūnawī must have addressed here concerns the Sufi convention that tașawwuf and the mystical experiences of gnostics cannot be subjected to any criterion, expressed poetically by Ibn 'Arabī:

The sciences of taste have no method (tariq $)$

Specified by proofs for the intellects

Except working according to the data of the religious law

And holding to a worldly law (nāmūs) accompanied by acceptance.

As well as the concern of a stern and proud speaker of truth

Providing better guidance [proof] for a weak being than anything else does. $^{89}$

As is understood from the first verse, Ibn 'Arabì is of the view that tașawwuf has no universal method or criterion of truth. On the contrary, according to one of the most important quasi-axioms of Akbarian Sufism- "There is no repetition in self-disclosure (la takrārf $f_{\imath}$-tajalli $)^{\prime 90}$ — the Real never manifests Himself in a single form twice. In this case, as Chittick puts it, "[t]here is no question of agreement" among Sufis, "since there is no argument. It is simply that each person who has traveled the path to God speaks from his own viewpoint and recounts his own experience."91 Admitting this principle, Qūnawī tries to interpret it in a way that allows some kind of universal knowledge or

\footnotetext{
88 Qūnawī, Miftāḥ al-ghayb, 9.2-12.

89 Ibn 'Arabī, Dīwān al-Shaykh al-Akbar Ibn 'Arabī, ed. by M. Qajja (n.p.: Dār al-sharq al-'arabī, n.d.), 283.8-10; English trans. in Franz Rosenthal, "Ibn 'Arabī between Philosophy and Mysticism," Oriens 31 (1988), 6-7.

9o Ibn 'Arabī attributes this principle to the famous Sufi author Abū Ṭālib al-Makkī (d. 996), quoting him as saying that "God never discloses Himself to two individuals, nor in a single form twice” (Chittick, The Sufi Path of Knowledge, 103). See also Qūnawī, Miftāh al-ghayb, 13.5-6; and Fanārī, Mișbāh al-uns, 101.5-7.

91 Chittick, The Sufi Path of Knowledge, 229.
} 
science. This principle, he interprets, is only meant to emphasize that tașawwuf is too general and too large an area to be controlled by one normative canon or restricted by one certain criterion. On the contrary, for Qūnawī, it is established among the perfect men of verification that Sufism has various criteria that change according to a range of different factors, such as the level, divine name, station, state, time, individual, etc. That is to say, each of these factors requires different rules to differentiate between the divine, angelic (al-ilq $\bar{a}$ al-

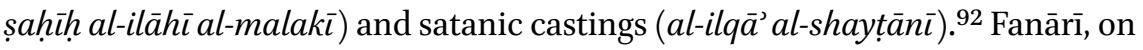
the other hand, prioritizes the religious law $\left(\right.$ shar $\left.^{c}\right)$ as the criterion of Divine Science, as Ibn 'Arabì did in the second verse above. The criterion of differentiation, he says, is the measure of the religious law; that which brings closeness to God is angelic, while that which is religiously disapproved is satanic. As for the permitted things, they belong to the latter group if they are closer to whimsical desires, and to the former group if they are not so. ${ }^{93}$

In his Miftăh al-ghayb, Qūnawì introduces a number of principles sometimes called "the principles of verification (qawä'id al-tahqīq),"94 but he is not clear there about the status of these principles in the demonstrative scheme of Divine Science. In his I Ijāz al-bayān, however, he gives very important details about the way in which he views these principles:

[T6] Know that this introduction includes universal principles, some of which help to understand the others [...]. Each one of these principles comprises a body of problems related to the roots of the realities (ummahät al-haqāi iq) and divine knowledge, some of which are proven by means of religious proofs, some through rational proofs and others by experiential, inspirational demonstrations (bi-l-barāhin al-dhawqiyya al-kashfiyya). None of those who realize the enlightening unveilings and clear, complete tastings (al-adhwāq al-tāmma al-jaliyya) could oppose them. This is because each community [of science] has principles and premises about the truth of which they are in agreement and which they take for granted. These are part of their criteria, upon which they depend and to which they refer. Whosoever accepts these from the verified people of this science, it turns out to be easy for him to form valid syllogisms and complete proofs from them ...95

92 Qūnawī, Miftāh al-ghayb, 7.11-8.4.

93 Fanārī, Miṣbāḥ al-uns, 50.10-13.

94 Fanārī uses this term in its singular form, see Fanārī, Miṣbāḥ al-uns, 104.12.

95 Șadr al-Dīn al-Qūnawī, Ijāaz al-bayān fì tafsìr umm al-Qur'ān, ed. by J. al-Āshtiyānī (Qum: Bustān-i kitāb, 1381), 17 . 
Here Qunnawī makes it evident that the principles of verification serve as the self-evident, or accepted, principles of Divine Science and as the premises of demonstrations to prove its problems. But perhaps more important is that he clarifies that what he had in mind when discussing the criteria of Divine Science was the body of accepted propositions that will serve as the foundation of inferences to solve its problems, rather than a method or methodology that may constitute an alternative to the logic of philosophers. Qūnawi himself acknowledges in the last sentence above that logic should be used in the procedures of deriving conclusions from the posited principles and postulates, which accounts for the abundance of logical inferences in the writings of Qūnawì and Fanārī. That is to say, although they are rather sceptical of reason and rational reasoning as means of acquiring knowledge of the ultimate essences of things as well as other subjects of metaphysics, and they have fundamental problems with the metaphysics underlying and motivating Avicennan logic, logic as an entirely formal and neutral tool of necessarily deriving conclusions from admitted premises seems to have been given a relatively respected place in their system. ${ }^{96}$

\section{5 Conclusion}

In this paper, I have presented and tried to assess the attempts by Qūnawi and Fanārī to reorganize and systematize tașawwuf on the groundwork laid by Ibn 'Arabì and according to the theory of demonstrative science developed first by Aristotle and elaborated by Avicenna. Although the two Akbarian Sufis are generally faithful to the Avicennan theory, they make certain modifications, one of which, for example, is Qunnawīs claim that the sciences investigate the reality, or existence, of their subject matter as well as their essential accidents and attachments. This leads them to hold some logically problematic positions, because the sciences differ from each other by virtue of their respective subject matter; thus, if there is no established subject to examine beforehand, there can be no science to examine it. Moreover, according to the Avicennan theory, the sciences aim to prove propositions under question, which depend on the subject matter, because they concern its essential accidents; if the subject matter

96 Surviving in Islamic scholarship and sneaking even into its most removed areas, like Sufism, this achievement of logic could not have been realized, I think, without Ghazāli’s tireless efforts to prove to Muslim religious scholars that logic can be dissociated from its metaphysical extensions. See Oliver Leaman, "Islamic Philosophy and the Attack on Logic," Topoi 19 (2000), 17. 
is taken as one of these questions, this necessarily leads to circularity. Fanārī regards the highest science as an exception to the rule that any given science cannot investigate its own subject matter, considering that there is no science above it to prove the reality of that subject matter.

Qūnawi makes another modification to the subject matter of metaphysics by maintaining that existence qua existence, or Absolute Existence, is identical with the Real, or God. Given that a scientific branch investigates the reality of its subject matter, Qūnawī and particularly Fanārī set about in-depth discussions to prove the real existence of Absolute Existence and its identity with God. For them, however, the true reality of Absolute Existence lends Himself by no means to any kind of investigation because $\mathrm{He}$ is beyond all the ways of human knowledge, and so Divine Science takes as its subject the Real's relation to the universe and the relation of the universe to Him. The identification of Absolute Existence with God raises vexatious issues for the Sufis as well. For according to most philosophers and theologians, absolute existence is one of the secondary intelligibles, which have no referent outside the mind. This is why Taftāzānī comes up with harsh criticisms against the idea of unity of existence (wahdat al-wujūd), and Fanārī tries to meet them in his Miṣbāḥ al-uns.

Besides a subject matter, principles and problems, Qūnawì claims that Divine Science has a criterion, which distinguishes true claims from the false within it, and which plays the same role as logic does in relation to the rational sciences. At first glance, this claim may seem to suggest that Qūnawì has a methodology in mind, which is an alternative to-and more appropriate for Divine Science-Avicennan logic, but on closer investigation it is revealed that by the criterion Qunnawī meant some basic and accepted premises that would play the role of axioms or postulates of the rational sciences.

\section{Acknowledgments}

This research was funded by the European Research Council (grant agreement ID 682779). I am deeply indebted to my teammates in the Epistemic Transitions in Islamic Philosophy, Theology, and Science research group in Jyväskylä, Jari Kaukua, Nathan Spannaus, Hadel Jarada, Davlat Dadikhuda, and Kutlu Okan for their invaluable comments on the earlier drafts of this paper. 


\section{Bibliography}

'Afîfì, Abū al-A'lā. "Al-A'yān al-thābita fī madhhab Ibn 'Arabī wa-l-ma'dūmāt fī madhhab al-mu'tazila." In al-Kitāb al-tidhkārī Muhyȳ al-Dìn ibn 'Arabì fì al-dhikrā al-miawiyya al-thāmina li-mülādih. Edited by I. Madkour. Cairo: Dār al-kutub al-‘arabī, 1969, 209220.

Ahmad, 'Azmī T. al-Sayyed. al-Ghazālı̀s Views on Logic. PhD dissertation. Edinburgh, 1981.

al-'Ajam, Rafīq. al-Manțiq 'inda l-Ghazālī. Beirut: Dār al-mashriq, 1989.

Arisțū. Manțiq Arisțū. Edited by A. Badawī. Beirut: Dār al-qalam, 198o.

Atçl, Abdurrahman. "Greco-Islamic Philosophy and Islamic Jurisprudence in the Ottoman Empire (1300-1600): Aristotle's Theory of Sciences in Works on Ușül al-Fiqh.” The Journal of Ottoman Studies 41 (2013): 33-54.

Atpazārī, Uthmān Faḍlī. Miṣbāḥ al-qalb sharḥ Miftāḥal-ghayb. Mss Süleymaniye Yazma Eser Kütüphanesi, Hacı Mahmut Efendi 2334.

Aydın, İ. Hakkı and Görgün, Tahsin, "Molla Fenari," in Türkiye diyanet vakfı İslam ansiklopedisi (DIA) 30 (2005): 245-8.

Barnes, Jonathan. "Aristotle's Theory of Demonstration." Phronesis 14 (1969): 123-52.

Barnes, Jonathan. "Introduction." In Aristotle. Posterior Analytics. Translated by Jonathan Barnes. Oxford: Clarendon, 1993, xi-xxii.

Chittick, William C. "The Last Will and Testament of Ibn 'Arabi's Foremost Disciple Sadr al-Din Qunawi." Sophia Perennis 4 (1978): 43-58.

Chittick, William C. "Mysticism versus Philosophy in Earlier Islamic History: The alṬūsī, al-Qūnawī Correspondence." Religious Studies 17 (1981): 87-104.

Chittick, William C. The Sufi Path of Knowledge. Albany: SUnY Press, 1989.

Chittick, William C. The Self-Disclosure of God: Principles of Ibn al-Arabï’s Cosmology. Albany: SUnY Press, 1998.

Dagli, Caner K. Ibn al-'Arabī and Islamic Intellectual Culture. London \& New York: Routledge, 2016.

Demirli, Ekrem. Sadreddin Konevîde bilgi ve varlık. İstanbul: Kapı, 2014.

Eichner, Heidrun. "Al-Fārābī and Ibn Sīnā on 'Universal Science' and the System of Sciences: Evidence of the Arabic Tradition of the Posterior Analytics." Documenti e studi sulla tradizione filosofica medievale 21 (2010): 71-95.

al-Fārābī. Ihṣâ̄’ al-'ulūm. Edited by 'A. Abū Malhạam. Beirut: Dār wa-maktabat al-hilāl, 1996.

al-Fanārī, Muḥammad b. Ḥamza. Miṣbāḥ al-uns. In Miftāḥ al-ghayb wa sharḥuhu Miṣbāh al-uns. Edited by M. Khājavī. Tehran: Intishārāt-i mawlā, 1374.

al-Fanārī, Muḥammad b. Ḥamza. Fuṣūl al-badā'i $f \grave{\imath}$ uṣūl al-sharā̉ic Edited by M.Ḥ. Ismāīil. Beirut: Dār al-kutub al-'ilmiyya, 2006.

al-Fanārī, Muhammad b. Hamza. Sharh al-Īsāghūjī. In Tam kayıtlı Fenarive KavliAhmed. İstanbul: Salah Bilici, 1985 . 
Faruque, Muhammad U. "Mullā Șadrā on the Problem of Natural Universals." Arabic Sciences and Philosophy 27 (2017):269-302.

Fūda, Saīì. Fatḥ al-wadūd bi-sharh risāla al-Sayyid al-Sharīf al-Jurjānī fì waḥdat alwujūd. N.p.: Manshūrāt al-aṣlayn, 2011.

al-Ghazālī, Abū Ḥāmid. al-Munqidh min al-ḍalāl. in Majmūéa rasāil al-Imām al-Ghazālī. Edited by A. Shams al-Dīn. Beirut: Dār al-kutub al-'ilmiyya, 1988, 194-228.

al-Ghazālī, Abū Hāmid. al-Qisțās al-mustaqīm. Edited by M. Bayjū. Damascus: alMațba'a al-ilmiyya, 1993.

al-Ghazālī, Abū Ḥāmid. al-Musțașā min 'ilm al-usūl. Edited by M. 'A. 'Abd al-Shāfī. Damascus: al-Mațbaca al-'ilmiyya, 1993.

Gürer, Betül. Molla Fenarinin varlıkve bilgi anlayışı. İstanbul: İnsan, 2016.

Heer, Nicholas. “Al- Jāmī’s Treatise on Existence." In Islamic Philosophical Theology. Edited by P. Morewedge. Albany, NY: SunY Press, 1979, 223-256.

Ibn 'Arabī. Dīwān al-Shaykh al-Akbar Ibn 'Arabī. Edited by M. Qajja. N.p.: Dār al-sharq al-'arabī, n.d.

Ibn 'Arabī. al-Futūḥāt al-makkiyya. Cairo: Dār al-kutub al-'arabiyya al-kubrā, 1911.

Ibn Khaldūn, 'Abd al-Raḥmān. al-Muqaddima. Edited by 'A.M. al-Darwīsh. Damascus: Dār yacrub, 2004.

Ibn Sīnā. al-Ishārāt wa'l-tanbīhāt. Edited by S. Dunyā. Cairo: Dār al-māārif, n.d.

Ibn Sīnā. al-Shifä̀) al-Manțiq I: al-Madkhāl. Edited by A. Anawātī et al. Cairo: al-Mațba‘a al-amīriyya, $195^{2}$.

Ibn Sīnā. al-Shifä’, al-Manțiq v: al-Burhān. Edited by A. 'A. al-'Afîfī. Cairo: al-Maṭba'a alamīriyya, 1956.

Ibn Sīnā. al-Shifā’: al-Ilāhiyyāt. Edited by A. Anawātī and S. Zāyed. Cairo: al-Hay’a al'āmma li-shu'ūn al-mațābi' al-amīriyya, 196o.

Ibn Sīnā. Kitāb al-Najāt. Edited by M. Fakhrī. Beirut: Dār al-āfāq al-jadīda, 1982.

al-İjī, 'Aḍud al-Dīn ‘Abd al-Raḥmān, al-Mawāqiff fı 'ilm al-kalām. Beirut: 'Ālam al-kutub, n.d.

al-Iṣfahānī, Shams al-Dīn. Tasdīd al-qawā'id fì sharḥ Tajrìd al-aqāंid. Edited by K. Ḥ. al'Adwānī. Kuwait: Dār al-ḍiyā', 2012.

Iznīqī, Muḥammad b. Quṭb al-Dīn. Fatḥ Miftāḥ al-ghayb. Edited by A. Rāshidiniyā. Tehran: Intishārāt-i sokhan, 1395.

Izutsu, Toshihiko. The Concept and Reality of Existence. Tokyo:The Keio Institute of Cultural and Linguistic Studies, 1971.

Izutsu, Toshihiko. "The Problem of Quiddity and Natural Universal in Islamic Metaphysics." In Dirāsāt falsafiyya muhdāt ilā l-duktūr Ibrāhīm Madkūr. Edited by U. Amīn, 131-177. Cairo: al-Hay’a al-mıșriyya al-āmma li-l-kitāb, 1974.

Izutsu, Toshihiko. Sufism and Taoism: A Comparative Study of Key Philosophical Concepts. Berkeley: University of California Press, 1984.

Kāshif al-Ghițā, 'Alī. Naqd al-ārā' al-manțiqiyya wa-ḥall mushkilātihā. Beirut: Mu’assasat al-nu'mān, 1382. 
Leaman, Oliver. "Islamic Philosophy and the Attack on Logic." Topoi 19 (2000): 17-24. Marmura, Michael E. "The Fortuna of the Posterior Analytics in the Arabic Middle Ages." In Knowledge and the Sciences in Medieval Philosophy, vol. I. Edited by M. Asztalos et al. Helsinki: Suomen filosofinen yhdistys, 1990, 85-103.

Nakanishi, Yuki. "Post-Avicennian Controversy over the Problem of Universals: Sacdaddīn at-Taftāzānī (d. 1389/9o) and Šamsaddīn al-Fanārī (d. 1431) on the Reality of Existence." In Islamic Philosophy from the 12th to the 14th Century. Edited by A. Al Ghouz. Göttingen: Bonn University Press, 2018, 353-71.

al-Qayșarī, Dāwūd. Risāla fì 'ilm al-tașawwuf. In al-Rasāil li-Dāwūd al-Qayșarī. Edited by M. Bayrakdar. Kayseri: Kayseri büyükşehir belediyesi, 1997, 105-33.

al-Qayṣan̄̄, Dāwūd. Sharḥ Fuṣūṣ al-hikikam. Edited by Ḥ.Ḥ. al-Āmulī. Qum: Bustān-i kitāb, 1382.

al-Qūnawī, Șadr al-Dīn. al-As'ila. In Annäherungen. Edited by Gudrun Schubert, 47-85. al-Qūnawī, Șadr al-Dīn. Maktūb ākhar min al-Qūnawì yudāfi' fìhi 'an kitābihi Rashḥ albāl. In Annäherungen. Edited by Gudrun Schubert, 130-9.

al-Qūnawī, Șadr al-Dīn. al-Risāla al-mufșiha. In Annäherungen. Edited by Gudrun Schubert, $15^{-46 .}$

al-Qūnawī, Ṣadr al-Dīn. Miṣbāḥ al-uns. In Miftāḥ al-ghayb wa sharḥuh Miṣbāḥ al-uns. Edited by M. Khājavī. Tehran: Intishārāt-i mawlā, 1374.

al-Qūnawī, Șadr al-Dīn. Íjāz al-Bayān fì tafsīr umm al-Qur'ān. Edited by J. al-Āshtiyānī. Qum: Bustān-i kitāb, 1381.

al-Rāzī, Quṭb al-Dīn. Sharh al-Mațāiic Edited by U. al-Sācīdī. Qum: Dhawi l-qurbā, 1433. Rosenthal, Franz. "Ibn 'Arabī between Philosophy and Mysticism." Oriens 31 (1988): 135 .

Sabra, Abdulhamid I. "Avicenna on the Subject Matter of Logic." The Journal of Philosophy 77 (1980): 746-64.

Schubert, Gudrun (ed.). Annäherungen: Der mystisch-philosophische Briefwechsel zwischen Șadr ud-Dīn-i Qōnawì und Nașìr ud-Dīn-i Ṭūsī. Beirut: al-Shirka al-muttahida li'l-tawzī', 1995 .

Shaker, Anthony F. Thinking in the Language of Reality: Șadr al-Dīn Qūnawī (1207-74CE) and Mystical Philosophy of Reason. N.p.: Xlibris, 2015.

Szabó, Árpád. “Greek Dialectic and Euclid's Axiomatics." In Problems in the Philosophy of Mathematics. Edited by I. Lakatos. Amsterdam: North-Holland Pub., 1967, 1-8. al-Taftāzānī, Sa'd al-Dīn Mas'ūd. Sharh al-Maqāsid. Edited by 'A. 'Umayra. Beirut: 'Ālam al-kutub, 1998.

Todd, Richard. The Sufi Doctrine of Man: Șadr al-Dīn al-Qūnawì’s Metaphysical Anthropology. Leiden: Brill, 2014. 